\title{
Comparative Analysis of the Quality Perception in Public Spaces of Duzce City
}

\author{
Elif Kutay Karacor, Ezgi Akcam \\ Landscape Architecture Department, Forestry Faculty, Duzce University, Duzce, Turkey \\ Email: elifkaracor@yahoo.com
}

How to cite this paper: Kutay Karacor, E., \& Akcam, E. (2016). Comparative Analysis of the Quality Perception in Public Spaces of Duzce City. Current Urban Studies, 4, 257266.

http://dx.doi.org/10.4236/cus.2016.43017

Received: July 15, 2016

Accepted: August 9, 2016

Published: August 12, 2016

Copyright $\odot 2016$ by authors and Scientific Research Publishing Inc. This work is licensed under the Creative Commons Attribution International License (CC BY 4.0).

http://creativecommons.org/licenses/by/4.0/ (c) (i) Open Access

\begin{abstract}
Public spaces in urban areas were affected from neoliberal policies in terms of their management and ownership. Accordingly, several researchers handled public spaces from different perspectives considering on advantages or disadvantages of neoliberal policies. Four key attributes of successful places: accessibility, comfort, socialization, and activity are accepted as quality indicators of today's urban spaces and they became an outline for this study. The aim of this study is to evaluate the quality of different type public spaces and to determine the reason why these differences. Therefore, quality differences resulting from management and ownership were evaluated in scope of public space literature. Our findings put forward that ownership of spaces is not a significant factor perceiving the quality of spaces. Besides, publicly owned urban spaces were found as not always preferable and the ownership was not a basis factor for quality perception.
\end{abstract}

\section{Keywords}

Public Space, Ownership, Management, Quality Perception

\section{Introduction}

The "public" term is originated from the Latin and it refers to a relationship between people, society, and the state. Public is defined as the opposite of private, and so public space is often defined in terms of its distinction from the private realm of the household (Madanipur, 2010). Public space relates to all parts of built and natural environment, public and private, internal and external, urban and rural, where people access without any restriction. All streets, open spaces, parks, open countryside, squares, shopping malls, rail or bus stations, libraries, town halls, religious buildings, and other rights of way whether predominantly in residential, commercial or community/civic uses are in- 
cluded in public spaces (Carmona et al., 2008).

According to UN Habitat (2015), there is a remarkable increase in the number of cities that have managed to use public space as a key for urban development. Especially city governors have used public space to improve mobility and access to basic services, making the environment safer, stimulating economic activity, preserving historical and cultural assets or facilitating urban renewal and inclusiveness. UN Habitat has promoted the use of public space for more than a decade as an implementation strategy for projects on urban planning, housing and slum upgrading, urban safety, and basic services.

Together with neoliberal policies that accelerated after the 1980's, public spaces have differentiated in terms of management and ownership. Whereas several researchers see the privatization of public spaces as a normal process (Loukaitou-Sideris \& Banerjee, 1998), others claim that privatization of public spaces could be a disadvantage for social sustainability since leading some exclusions (Sennett, 1996; Low \& Smith, 2013). However, there are few studies about how the quality of public spaces is affected by management or ownership issues. The aim of this study is to evaluate the quality of different type public spaces and to determine reason why these differences. In this context, the quality of public space types which were publicly or privately owned was rated by urban design experts and what kind of reasons would be led to these results were discussed.

\section{Quality Indicators of Public Spaces}

Jacobs (1961) as one of the first to focused on the urban quality subject, and she emphasized activity as the quality indicator of urban environment. In recent years, Gehl (2011) claim that successful built environment arisen from ordinary daily street life where several activity occurs and people may interact. Montgomery (1998), idealized successful urban places by combining activity, meaning and physical setting. In following years, indicators of idealized places were redefined as depending on the change of social life. According to Carmona et al. (2003), the key attributes of successful places are; accessible that people are engaged in activities; comfortable and has a good image; and sociable place where people meet each other and take people when they come to visit. These four key attributes are accepted as quality indicators of today's urban spaces and they became an outline for this study.

\subsection{Accessibility}

Accessibility of public spaces is discussed under the physical and visual access terms in the literature. Physical accessibility refers to the proximity and ease with which buildings or places can be reached (Lotfi and Koohsari, 2009a), and visual accessibility refers to the places can be seen by people. It is expected from public spaces that their access should be provided for all groups in the society. As noticed by Madanipour (2010), accessibility is seen as a key feature of public space. The places which are not accessible can not be considered as truly public. So their inclusiveness is developed with their access. Therefore, publicness and access of urban places which are invisible from the 
outside or could not be passed through inside are declined. Public spaces which are physically surrounded and accessed after surveillance by security systems and the ones that closed to the living area of a specific social groups are controversial. Besides, Lotfi \& Koohsari (2009b) emphasize that urban designers should create urban spaces that everybody has easy access to urban services since accessibility reflects the quality of urban environment. Gender, income level, age, ethnicity plays an important role in accessibility. Women, low-income people, children and ethnic minorities are disadvantaged for using public spaces in most of societies. This case could resulted from inability to driving car, insufficient public transport services or political reasons. Physical access to spaces is also associated with the proximity of public transportation and presence of walkable streets. Public spaces which are served by transport has a significant effect on the quality, usability and viability of it (Williams and Green, 2001).

\subsection{Comfort}

As suggested by Holland et al. (2007), people want to stay and spend more time in public spaces that offer a degree of comfort. Special events draw attention and make places more interesting and charming. People are more likely to play around if there is somewhere comfortable to sit, especially if there is also some protection from the weather. Perceptions about safety and cleanliness, are often prominent in people's minds as more tangible issues such as having a comfortable place to sit (Placemaking Chicago, 2016). Crime perception and fear of crime influence people's patterns of use of public spaces (Lloyd and Auld, 2003). Outdoor human comfort in an urban climate is another important comfort element that affects public space preferences and usages. Outdoor human comfort may be affected by several parameters such as wind speed, air temperature, relative humidity, solar radiation, air quality, human activity, clothing level, etc. (Stathopoulos et al., 2004). In addition, the perception of sounds is an important comfort element in public spaces. A lower background sound level makes people feel quieter. Lower background sound level is important to create a comfortable acoustic environment in public spaces (Yang and Kang, 2005). Comfortable public spaces should be designed as pedestrian focused, and motorized vehicles should draw back for safety needs. Therefore, it is important how pedestrian movement is achieved.

\subsection{Socialization}

People are unable to develop without human interactions, and those interactions require venues. Only family members and colleagues are not enough to accomplish a larger, vital, and functional community. Therefore, public spaces are needed for contact, knowledge, and stimulation (Efroymson et al., 2009; Gehl, 2011). Public spaces play an important role in the social life of urban inhabitants that bring together different social groups, contribute to the development of social memory, and develop communication in the society. All these developments trigger democracy, mutual understanding, and tolerance. According to PPS (2016), when people see friends, meet their neighbors, and communicate with strangers, they tend to feel a stronger sense of place 
or attachment to their community-and to the place. Public spaces possess special meanings that accumulate over time and these meanings contribute to meeting diverse needs. Users of public spaces acquire a sense of wellbeing for different reasons (Cattell et al., 2008). According to Carmona et al. (2008), public spaces can help to reduce crime and anti-social behavior, provides a venue for social events and foster neighborliness.

Besides, public spaces provide opportunities for people to perform their public roles. This means that public space is multi-functional, and also, by implication, that there are different types of space to which it can be put. This includes, of course, meeting places and spaces which symbolize shared memories, which leads us to consider the role of meaning in place making (Montgomery, 1998).

\subsection{Activity}

Activities can be seen as the basic building blocks of public spaces. Public spaces that having something to do gives people a reason to come to a place. If there was nothing to do, public spaces would be empty and it means that something is wrong (PPS, 2016). Group activities could increase socialization in public spaces by encouraging physical activity, and healthy living by recreational opportunities. According to Gehl (2011), people activities attract other people, and public spaces which have things to do could attract other people as well. If there are things to do people want to spend time in public spaces. Opportunities to act, things to do, and activities to be involved in should be considered more than walking and sitting opportunities.

The activities are needed to address different age and gender groups, and the spaces should be held by taking into consideration of disabled and elderly people. Furthermore, public spaces should be designed as to be used throughout the day and in different seasons. Empty public spaces would create a domino effect on the people, and people could not desire to visit such places that not preferred by others.

\section{Study Area and Method}

\subsection{Study Area}

Duzce city, our study area, is located between two metropolitan cities-Ankara and Istanbul-and its population increases due to migration from other cities depending on its strategic location. We selected this city as our study area because of its spatial transformation, especially after the 1999 earthquakes. After the earthquakes, management and ownership of several public spaces have changed. The government incentivized the private sector to create job opportunities for inhabitants of the city. After that, the city was rapidly migrated from both other cities and its surrounding rural areas. Together with new residential areas, several urban services, shopping malls, and recreational facilities emerged in the city center; on the other hand, some public spaces turned into neglected vacant areas and they were visited by less people.

Public space types of this study were selected from urban space classification of Carmona (2010) that considering management and ownership of spaces. Carmona 
(2010) criticized several urban space classification since public and private realms are increasingly intertwined, and identified twenty urban space types in four categories (positive, negative, ambiguous and private), representing a continuum from clearly public to clearly private space. In this study, three positive spaces which are considered as high in publicity and three ambiguous spaces which are unclear in terms of publicity have been evaluated. Anit Park, Asar Riverside, and Inonu Park are considered as positive spaces; and Krempark Shopping Mall, Public Market, and Spor Street as ambiguous spaces in Duzce city. The reason why the selection of public spaces from positive and ambiguous spaces is that questioning the influence of management and ownership on the quality of these spaces, and only these two categories include public space types. Asar River is flowing through the city and it led to a flood in 1998, after that, most of the residences and work spaces were damaged. Since from the 2000's several improvements were employed and several public spaces were created along this riverside by the local authorities. Spor Street is that one of the oldest pedestrianized streets has a vibrant street life with a row of shops. There are several cafes, passages and boutiques on the street which are located in the heart of the city. Similar to other city parks, Inonu Park was built in 1940s to support modernization project in The Republic of Turkey that involved especially women into public life. This park that connected with Spor Street is the biggest green public area of the city. Anit Park which can be qualified as civic space is used for the celebration of national days or public protests by several activist groups. This civic space that located between the Duzce City Governorship and Inonu Park is the biggest gathering and meeting area in the city center. Krempark Shopping Mall is the only shopping mall in the city was opened in 2012. Before the opening of this mall, the inhabitants of the city fulfilled their shopping needs in the local shops which are located on the main streets. The public market is located out of the city center compared to other public spaces, and it was actively worked at least two days in a week. The public market that bringing together local producers and buyers is the biggest public market in the city and it is important for agriculture-based economy for sustainable development (Figure 1).

\subsection{Method}

This study attempts to measure and compare qualities of the urban public spaces. We applied to expert panel method to measure six public space types in terms of four qualities: accessibility, comfort, socialization, and activity. The items of four quality indicators were drawn from PPS (2016) to measure the quality of urban spaces (see Appendix). A panel of 41 urban design experts who have been living in Duzce city was assembled to rate different public spaces with respect to these qualities. After that, descriptive statistics was applied to learn differences between public spaces in terms of quality indicators. These four quality indicators of public spaces were modeled by using a pie chart (Figure 1). In this model, each of the four indicators has an equal part of the circle. The concentric rings allow each of the four indicators to be measured on an ordinal, five-point scale ranging from 1 (strongly insufficient) to 5 (strongly sufficient). 

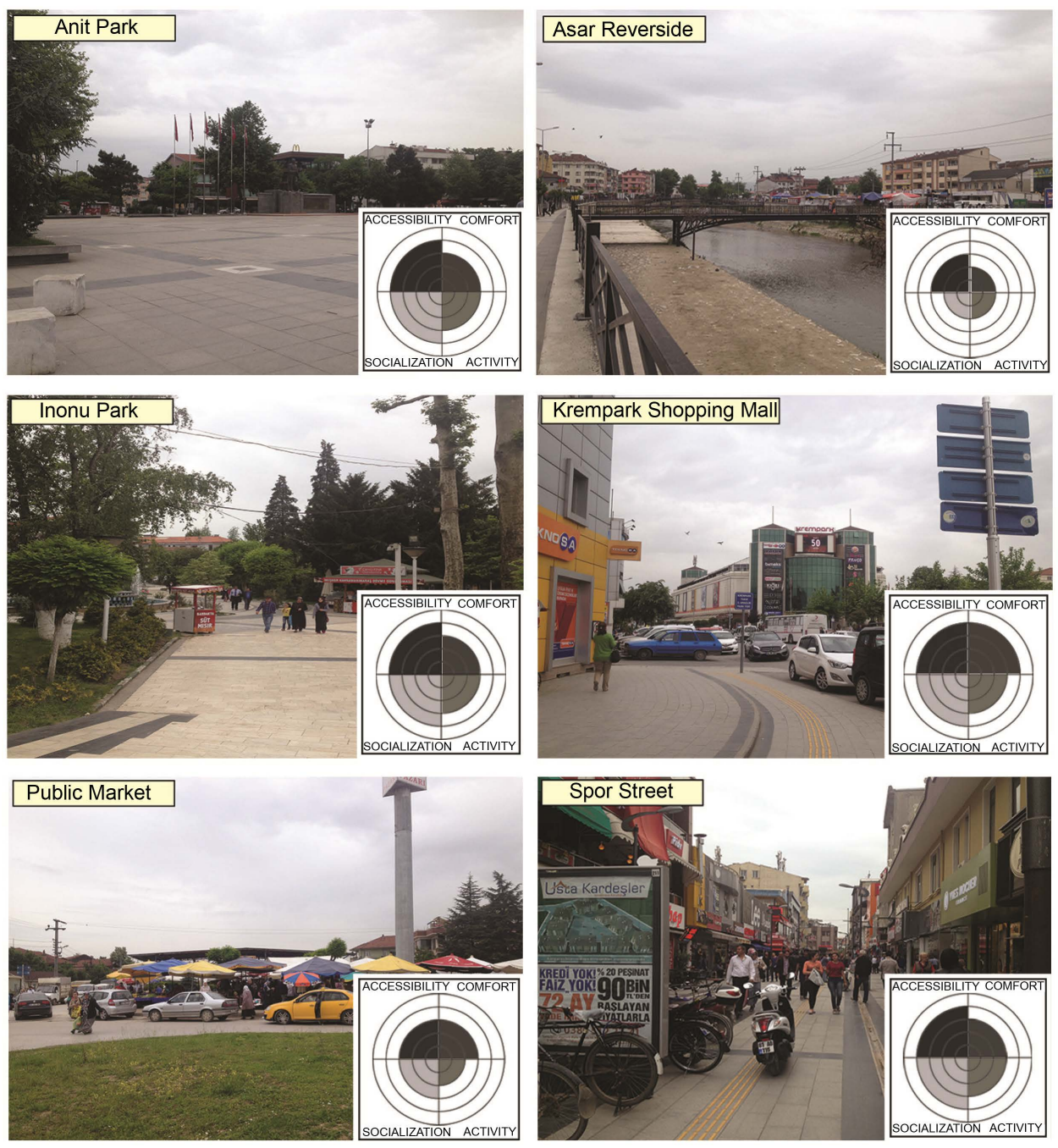

Figure 1. A visual display of the four quality indicators for six urban spaces Duzce city center.

\section{Results}

Descriptive statistics that shows the quality of urban public spaces are presented in Table 1. Whereas the lowest mean value was found in Public Market and the highest was found in Anit Park for accessibility. Accordingly, the lowest mean values were found for Asar Riverside and the highest ones were found for Krempark Shopping Mall in terms of comfort, socialization, and activity. Total quality indicators present similar results as shown in Table 1 .

Descriptive statistics of the study are modeled by using a pie chart in Figure 1. When considering on pie charts, Krempark Shopping Mall is seen as having the highest quality in terms of total quality scores. When analyzed within itself Krempark Shopping Mall, activity was found as the lowest quality indicator. Whereas Asar Riverside was found as having the lowest score in terms of total quality, accessibility was found as the highest quality indicator within itself. On the other hand, Anit Park, Inonu Park, and Spor Street have similar pie chart patterns in terms of quality indicators in Figure 1. 
Table 1. Descriptive statistics of public spaces in terms of quality indicators.

\begin{tabular}{|c|c|c|c|c|c|c|c|c|c|c|}
\hline & \multicolumn{2}{|c|}{ Accessibility } & \multicolumn{2}{|c|}{ Comfort } & \multicolumn{2}{|c|}{ Socialization } & \multicolumn{2}{|c|}{ Activity } & \multicolumn{2}{|c|}{$\begin{array}{c}\text { Total quality } \\
\text { scores }\end{array}$} \\
\hline & Mean & S.D. & Mean & S.D. & Mean & S.D. & Mean & S.D. & Mean & S.D \\
\hline Asar Riverside & 2.93 & 0.85 & 1.93 & 0.65 & 1.99 & 0.84 & 1.87 & 0.64 & 2.18 & 0.59 \\
\hline Spor Street & 4.07 & 0.62 & 3.15 & 0.61 & 3.96 & 0.74 & 2.92 & 0.78 & 3.53 & 0.53 \\
\hline Inonu Park & 3.75 & 0.90 & 3.09 & 0.61 & 3.53 & 0.75 & 3.01 & 0.72 & 3.34 & 0.59 \\
\hline Anit Park & 4.37 & 0.50 & 3.43 & 0.66 & 4.02 & 0.67 & 3.40 & 0.72 & 3.80 & 0.49 \\
\hline $\begin{array}{c}\text { Krempark } \\
\text { Shopping Mall }\end{array}$ & 4.10 & 0.64 & 3.78 & 0.65 & 4.22 & 0.69 & 3.49 & 0.75 & 3.89 & 0.53 \\
\hline Public Market & 2.75 & 0.97 & 2.50 & 0.77 & 2.67 & 0.98 & 2.19 & 0.76 & 2.55 & 0.74 \\
\hline
\end{tabular}

These three public spaces were found as high in quality in accessibility and socialization. However, they were considered relatively low in quality in terms of comfort and activity. Public Market was found as having a low quality level in terms of activity but has an average level in terms of accessibility, comfort, and socialization.

\section{Discussion and Conclusion}

Our findings demonstrated that ownership of spaces was not a significant factor perceiving the quality of spaces. Accordingly, publicly owned urban spaces could be perceived as low in quality because of several factors that influence on activity, comfort, and access. Similar to our findings, Nemeth and Schmidt (2011) suggest that both publicly and privately owned public spaces tend equally to encourage public use and access. Eventually, the socialization level of urban spaces can be provided depending on other three indicators. On the other hand, the management issue is highly connected with the quality perception of spaces. Although, over managed urban spaces are criticized since have restricted access for disadvantaged and marginal groups, the truth is that ordinary people do not want to come together and spending time with the others. Therefore, they prefer the urban spaces that which are safety and under the control of restricted access and security cameras. Increased terrorist attacks and fear of crime in recent years have led to spending more leisure times in over managed urban spaces such as shopping malls and thematic parks. Our study has supported this approach we found that Krempark Shopping Mall has the highest total quality compared to other public spaces. This finding could have resulted from its location, access by walking and public transportation, indoor human comfort, and accuracy for meeting with other people. Several researchers criticized shopping malls since having security control and limited access, and they claimed that these spaces are not the real public (Mitchell, 1995). Graham \&Aurigi (1997) claimed that shopping malls represent the erosion of genuine public space in today' cities.

Finding of Anit Park as high in quality in terms of comfort compared to Inonu Park and Spor Street is related to its indoor spaces that facilitate four season usage. The cities 
that have extreme weather conditions require indoor or semi-enclosed spaces to facilitate and create a public realm. Accordingly, privately owned consumption spaces are the only ones that provide seasonal comfort. On the other hand, Asar Riverside that can be called as natural/semi-natural urban space according to the classification of Carmona (2010) was found as having lowest total quality. This result shows that publicly owned urban spaces are not always preferable and requested to be visited spaces, and the ownership is not an essential factor for quality perception. Therefore, new approaches for the management of public spaces should be discussed. Especially, local governments are needed to be considered on how to transform public spaces into more attractive and inviting spaces.

As mentioned by Efroymson et al. (2009), together with neoliberal policies shopping malls have started to encourage consumption; parks, markets, walkways, and busy sidewalks encourages only interaction. Creating public spaces or keeping them under the control should not be seen as a necessity, unlike public spaces should be seen as vital for people's interactions, health, and well-being.

\section{References}

Carmona, M. (2010). Contemporary Public Space, Part Two: Classification. Journal of Urban Design, 15, 157-173. http://dx.doi.org/10.1080/13574801003638111

Carmona, M., De Magalhaes, C., \& Hammond, L. (2008). Public Space: The Management Dimension. New York: Routledge Press.

Carmona, M., Heath, T., Oc, T., \& Tiesdell, S. (2003). Urban Spaces-Public Places: The Dimensions of Urban Design. Oxford: Architectural Press.

Cattell, V., Dines, N., Gesler, W., \& Curtis, S. (2008). Mingling, Observing, and Lingering: Everyday Public Spaces and Their Implications for Well-Being and Social Relations. Health \& Place, 14, 544-561. http://dx.doi.org/10.1016/j.healthplace.2007.10.007

Efroymson, D., Thanha, T. T. K., \& Ha, P. T. (2009). Public Spaces: How They Humanize Cities. Dhaka: HealthBridge-WBB Trust.

Gehl, J. (2011). Life between Buildings: Using Public Space. Washington DC: Island Press.

Graham, S., \& Aurigi, A. (1997). Virtual Cities, Social Polarization, and the Crisis in Urban Public Space. The Journal of Urban Technology, 4, 19-52. http://dx.doi.org/10.1080/10630739708724546

Holland, C., Clark, A., Katz, J., \& Peace, S. (2007). Social Interactions in Urban Public Places. Bristol: The Policy Press.

Jacobs, J. (1961). The Death and Life of Great American Cities. London: Vintage Books.

Lloyd, K., \& Auld, C. (2003). Leisure, Public Space and Quality of Life in the Urban Environment. Urban Policy and Research, 21, 339-356. http://dx.doi.org/10.1080/0811114032000147395

Lotfi, S., \& Koohsari, M. J. (2009a). Measuring Objective Accessibility to Neighborhood Facilities in the City (A Case Study: Zone 6 in Tehran, Iran). Cities, 26, 133-140. http://dx.doi.org/10.1016/j.cities.2009.02.006

Lotfi, S., \& Koohsari, M. J. (2009b). Analyzing Accessibility Dimension of Urban Quality of Life: Where Urban Designers Face Duality between Subjective and Objective Reading of Place. Social Indicators Research, 94, 417-435. http://dx.doi.org/10.1007/s11205-009-9438-5 
Loukaitou-Sideris, A., \& Banerjee, T. (1998). Urban Design Downtown: Poetics and Politics of Form. California: University of California Press.

Low, S., \& Smith, N. (2013). The Imperative Public Space. In S. Low, \& N. Smith (Eds.), The Politics of Public Space. New York: Routledge.

Madanipour, A. (2010). Whose Public Space. In A. Madanipour (Ed.), Whose Public Space? International Case Studies in Urban Design and Development (pp. 237-243). New York: Routledge.

Mitchell, D. (1995). The End of Public Space? People's Park, Definitions of the Public, and Democracy. Annals of the Association of American Geographers, 85, 108-133.

Montgomery, J. (1998). Making a City: Urbanity, Vitality and Urban Design. Journal of Urban Design, 3, 93-116. http://dx.doi.org/10.1080/13574809808724418

Németh, J., \& Schmidt, S. (2011). The Privatization of Public Space: Modeling and Measuring Publicness. Environment and Planning B: Planning and Design, 38, 5-23. http://dx.doi.org/10.1068/b36057

Placemaking Chicago (2016). Comfort of Public Spaces. http://www.placemakingchicago.com/about/qualities.asp

PPS (2016). Project for Public Spaces. http://www.pps.org/

Sennett, R. (1996). Kamusal Insanin Cokusu [The Fall of Public Man]. Istanbul: Ayrinti Yayinlari.

Stathopoulos, T., Wu, H., \& Zacharias, J. (2004). Outdoor Human Comfort in an Urban Climate. Building and Environment, 39, 297-305. http://dx.doi.org/10.1016/j.buildenv.2003.09.001

UN Habitat (2015). Global Public Space Toolkit from Global Principles to Local Policies and Practice. Nairobi: United Nations Human Settlements Programme (UN-Habitat).

Williams, K., \& Green, S. (2001). Literature Review of Public Space and Local Environments for the Cross Cutting Review Final Report. Oxford: Oxford Brookes University, Department for Transport, Local Government and the Regions Research Analysis and Evaluation Division.

Yang, W., \& Kang, J. (2005). Acoustic Comfort Evaluation in Urban Open Public Spaces. Applied Acoustics, 66, 211-229. http://dx.doi.org/10.1016/j.apacoust.2004.07.011 


\section{Appendix}

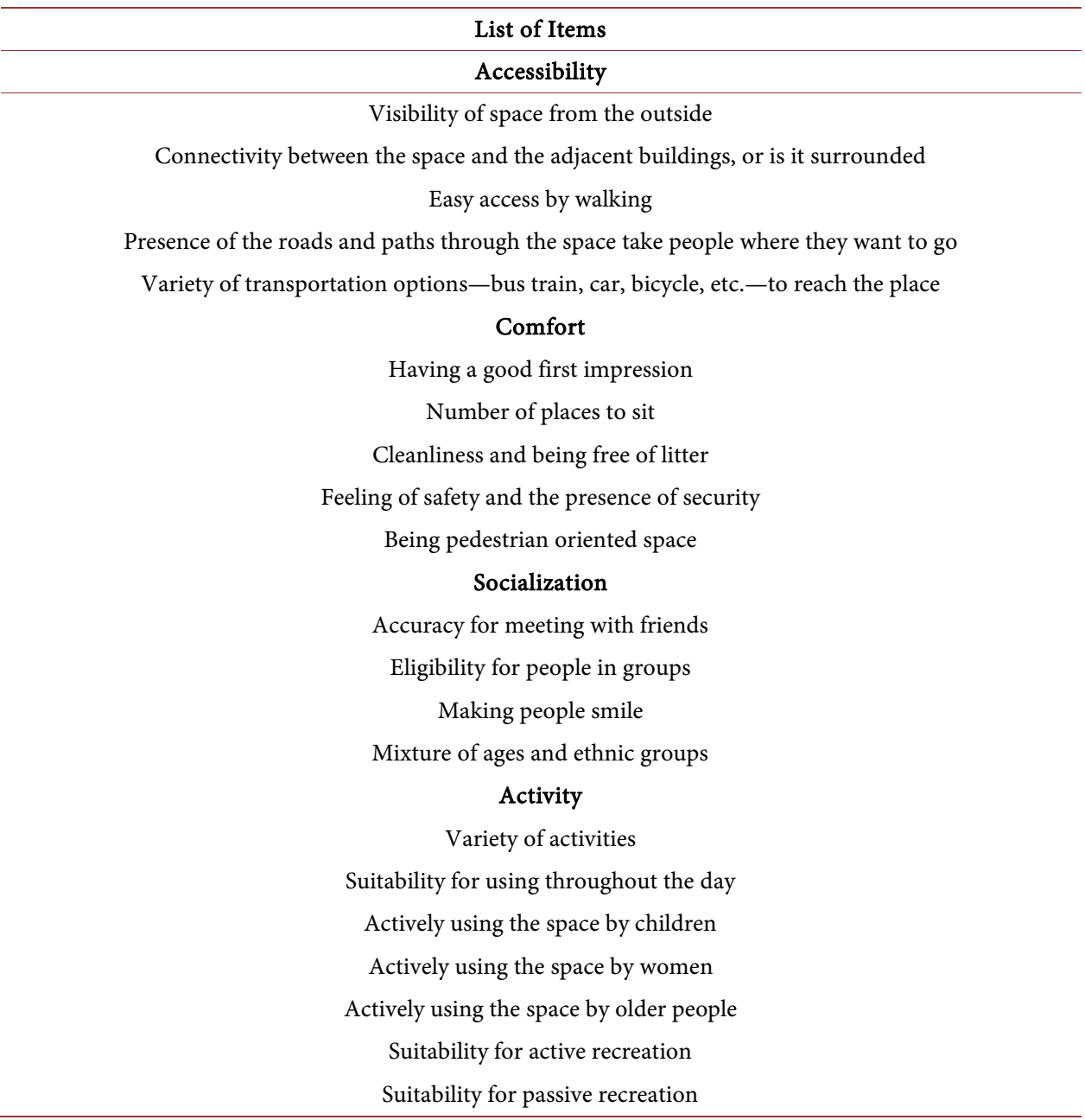

\section{Submit or recommend next manuscript to SCIRP and we will provide best service} for you:

Accepting pre-submission inquiries through Email, Facebook, LinkedIn, Twitter, etc. A wide selection of journals (inclusive of 9 subjects, more than 200 journals)

Providing 24-hour high-quality service

User-friendly online submission system

Fair and swift peer-review system

Efficient typesetting and proofreading procedure

Display of the result of downloads and visits, as well as the number of cited articles

Maximum dissemination of your research work

Submit your manuscript at: http://papersubmission.scirp.org/ 